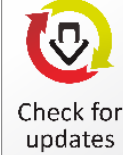

updates
Article Type: Research Paper

\section{Evaluation of Village Fund Allocation on Indonesia}

\author{
Anik Puji Handayani ${ }^{1 *}$ and Rudy Badrudin ${ }^{2}$
}

\begin{abstract}
This study focuses on evaluation on Village Fund Allocation through on examining the effect of the Village Fund Allocation on Capital Expenditure, Economic Growth, Poverty, and Social Welfare. Using secondary data and purposive sampling method, this study has 411 districts as the samples with criteria in 2015. This study used Partial Least Square (PLS) to predict relationships between variables. Before doing the analysis of PLS, Klassen typology analysis was conducted. In Klassen typology, the districts in Indonesia were grouped into 4 quadrants, namely quadrant I (developing area), quadrant II (prime area), quadrant III (potential area), and quadrant IV (backward area). PLS test results (using a sample of districts throughout Indonesia) indicate that all hypotheses are not supported. Whereas in the classification of Klassen typology (using samples in each quadrant) only in certain quadrants a hypothesis is supported. This shows that the Village Fund Allocation has not had a significant impact on the economy of the Indonesian people.
\end{abstract}

Keywords: Village Fund Allocation; Capital Expenditure; Economic Growth; Poverty; Social Welfare

\section{Introduction}

Since the beginning of regional autonomy in 2001, it has opened up opportunities for local governments to be responsible for managing their respective regional interests. Regional autonomy is a solution in dealing with various problems that occur due to the problem of disparity (inequality) of development both between the central and regional and between districts and cities [(Kuncorojati, 2017) and (Badrudin , 2015)]. This disparity occurs as a result of uneven development causing high poverty rate in Indonesia (Aziz, 2016). The statistics state that in general, the poverty rate in Indonesia in the period of 1998-2016 had decreased. However, in 2006, September 2013 and March 2015, it increased. The number of poor people in 2006 amounted to 39.30 million people. In March 2015, it increased to 28.59 million compared to September 2014 of 27.73 million and September 2015 in which it decreased to 27.76 million people compared to March 2016 of 28.01 million people.

The problem is not only the poverty rate. However, the level of disparity in Indonesia's human development is still relatively high. Indonesia's 


\section{Handayani \& Badrudin \\ Evaluation of Village Fund Allocation on Indonesia}

Human Development Index (HDI) in 2010 was recorded at $66.53 \%$ and $70.18 \%$ in 2016 . With the HDI of $70.18 \%$, this figure shows the status of Indonesia's HDI increased from the moderate to high category. This data shows that Indonesia is experiencing an increase in economic growth, but on the other hand, it has not overcome the level of development disparity between one area with other areas, both between provinces and between districts/ cities in one province. Poverty reduction and development disparity are the goals of the development (Siregar \& Badrudin, 2017). The economic growth should be able to significantly reduce the number of poor people (Ginting \& Dewi, 2013), which further it can accommodate low disparity or the equal distribution of income. Economic growth is the process of increasing the long term per capita output (Badrudin, Ekonomika Otonomi Daerah, 2017). Based on the explanation, it can be said that the ongoing development in Indonesia within that period was an exclusive development, not inclusive.

According to the United Nations Development Program (UNDP, 2009), the development of some countries is an exclusive development. It means that development only takes into account the growth aspect but does not take into account the absorption of manpower, poverty reduction, and environment so that sometimes there is high economic-growth accompanied by high unemployment and poverty rate, as well as environment damaged as a result of development process. Lin and Liu (2000) conducted research in China, found evidence that the key factor of economic growth in China is fiscal reforms in line with rural reforms. This study is directly proportional to Lai's research (1994) in Taiwan that the success of development strategies in Taiwan is largely determined by the development of industrial sectors in rural areas. In order to achieve equitable growth and economic development, development in Indonesia must start from the countryside. This is based on several reasons. First, almost all Indonesians live in rural areas. Second, although fiscal decentralization has been started since 2001, the data show that almost some of the basic problems in the country, such as poverty, low education, poor health, inadequate facilities and infrastructure, exist in village area. Therefore, as soon as possible, it is necessary to build a reform of understanding that village areas have strategic position in Republic of Indonesia. It can even be said that if village areas are advanced then the area and the country must be the same. Thus, it is no exaggeration to say that the countryside is the spearhead of regional and national development (Prasetyo, 2012).

To realize the goals, the government passed the Act No. 6 of 2014 on Villages. To run its authority in governing and managing governance and the interests of the people, the villages need a source of income. Village income is a vital resource for village administration. The philosophy of village funds is to improve the welfare and equity of village development through improving public services in the village, promoting village economy, addressing the gap between village development and strengthening the village community as the subject of development. The existence of village funds is expected to increase regional development because the village government gets the allocation of funds that will be used for the cost of development capital. The amount of village fund allocation disbursed in 2015 amounted to IDR 20.7 trillion. This amount is a fairly large amount. However, the allocation of village funds leads to potential 


\section{Handayani \& Badrudin \\ Evaluation of Village Fund Allocation on Indonesia}

irregularities in the field and inappropriate use. One of the causes is that the Government Regulation issued as a derivative of the law has not been socialized to the maximum and there has been no proper monitoring of the use of these funds.

Regional development is an effort to increase the capacity of local governments in running their government in physical development in the form of suggestions and infrastructure (Nugroho, 2012). Local governments in funding development activities for the benefit of the community use capital expenditure. The capital expenditures are allocated by local governments to fund development activities aimed at public interest. This activity resulted in the construction of various public facilities such as roads, bridges, telecommunications, electricity, school buildings and hospitals, markets and various other public facilities which can be utilized by the society (Badrudin, Ekonomika Otonomi Daerah, 2017). The capital expenditure and village fund allocation have different funding sources but both can promote economic growth. The increased economic growth is expected to reduce the level of poverty and improve the welfare of the community.

This research was motivated by Prasetyo's research (2012) which examined the Impact of Village Fund Allocation (VFA) in the Era of Fiscal Decentralization on Regional Economies in Indonesia. The results of his research show that VFA is able to improve the fiscal and economic performance of the region, able to reduce the number of poor people and increase the gross regional domestic product of the agricultural sector. In this study the implementation of VFA is regulated in Government Regulation No. 72 of 2005 , only $60 \%$ of local governments in Indonesia have implemented it.

In contrast to the research, this research is based on Law No. 6 of 2014 and has only been running for several years, so research based on these rules is still rarely done. This study aims to examine whether the management of the recently running village funds can have a positive impact on Indonesia's economic development in the era of inclusive economic development.

Theoretically, this research contributes in realizing development outcomes through VFA which is inclusive development, because, in inclusive development, development goals are meaningful by not only pursuing economic growth but also oriented to creating jobs so as to reduce open unemployment, reduce the poor, and reduce the income distribution gap between community groups. Thus this research supports the Stewardship Theory. Practically, the results of this study are expected to be used as material for consideration by the government in the formulation of policies on the implementation of VFA and Capital Expenditures (CE) in order to support Indonesia's Economic Growth (EG), by reducing poverty and increasing Social Welfare (SW).

\section{Literature Review and Hypotheses Development}

Stewardship theory is defined as a situation in which stewards do not have personal interests but are more concerned with principals' desires (Donaldson \& Davis, 1991). In 


\section{Handayani \& Badrudin \\ Evaluation of Village Fund Allocation on Indonesia}

this theory, the steward will behave according to mutual interests. When the interests of the steward and the owner are not the same, the steward will try to work together rather than oppose it, because the steward feels the common interest and behaves according to the owner's behaviour is a rational consideration because the steward looks more at the effort to achieve organizational goals (Raharjo, 2007). In connection with the public sector, the regional government as a Steward and the community as principal. The government strives to achieve a common goal of achieving community welfare. If the welfare has not been achieved, various efforts have been made by the government to achieve this by reducing poverty.

According to Kuznets in Badrudin (2017, p. 140) EG is defined as increasing the ability of a country to provide economic goods to its population. Djojohadikusumo in Badrudin (2017, p. 121) also defines EG as a process of increasing the production of goods and services in the economic activities of society. EG is a process of increasing the production capacity of an economy that is realized in the form of an increase in national income.

VFA is the budget used by the village government to empower the societies and implement the development managed directly by the village and society (Prasetyo, 2012). CE is a component of development expenditure on regional spending. The capital expenditures are allocated by local governments to fund development activities for the society. This activity results in the construction of various public facilities such as roads, bridges, telecommunications, electricity, school buildings and hospitals, markets and other public facilities that will be utilized by the society (Badrudin, 2017).

Poverty (PVT) is a problem in development characterized by unemployment and underdevelopment, which then increases into inequality. The poor are generally weak in their ability to work and have limited access to economic activity so that they are left behind by other societies having higher potential. The Human Development Index (HDI) is an index to explain how people can access development outcomes and earn income, health and education. EG is important to maintain the welfare of its people, but EG is not the end of human development. EG is used to improve human capabilities and how people use these capabilities.

According to Badrudin (2011), EG will affect the wealth of society. Increase in income in the community is indicated by the increased allocation of income for primary, secondary, and tertiary consumption. According to Prasetyo (2012), Indonesia's EG model is an economic model that focuses on stimulating the increase of people's income through the growth acceleration of economic sectors which is efficient and dynamic without taking into account the negative impacts on wider society like the depletion of natural resources and environmental damage. Considering this, thus it is necessary to have proper development planning and to give attention to environmental capacity.

Allocation of village funds is funds sourced from the central government, which are given to villages to build the village. The higher the village funds provided, the higher the level of village development. This increasing level of development can increase the eco- 
nomic activities of the community. Therefore, the higher the village funds, the higher the economic growth of the region. This opinion suggests that VFA has an important role in regional EG. VFA, according to Act No. 6 of 2014, about Village is the budget allocation for the village that comes from a central budget which is done by equally and equitably making the village-based programs effective. Prasetyo (2012) proves that VFA is able to improve fiscal performance and regional economy and be able to reduce the number of poor people and increase the gross domestic product of agricultural sector. While Ashari (2013) proved the role of VFA in the development of physical infrastructure in the Village Kelinjau Ilir still a little. It shows, when VFA is allocated properly, it will promote EG, improve social welfare and reduce poverty. Based on the description, the hypothesis in this study is as follows:

$\boldsymbol{H}_{1}$ : Village Fund Allocation has a positive effect on District Economic Growth in Indonesia

One form of economic development is the construction of infrastructure and facilities and infrastructure that support the activities of the regional government. Provision of infrastructure and facilities and infrastructure through capital expenditure. With the addition of infrastructure and improvements, it will boost the regional economic growth rate. Hakim and Wijayanti (2012) have proved in their research that increasing CE of the government which consists of land capital, equipment and machinery, and the other capital expenditures has a positive impact on EG. It is in line with the research conducted by Nurmainah (2013), CE of regional government, absorbed labour, and HDI has a significant effect and has a positive relation to EG in Central Java Province. This indicates when the increase in CE for development financing will be followed by EG. Based on the description, the hypothesis in this study is as follows.

\section{$\mathrm{H}_{2}$ : Capital Expenditure has a positive effect on District Economic Growth in Indonesia}

According to Ginting and Dewi (2013), PVT is a situation where household income is too low to meet basic needs. They find it difficult to buy food, homes, and clothing which are needed every day. This situation is spurred by the inequality of income, or in other words this poverty occurs because driven by income inequality that occurs in a country. Thus, PVT reduction is one of the development goals. Ginting and Dewi (2013), and Soejoto, Subroto, and Suyanto (2015) conducted that EG has a negative and significant effects on PVT, but not support to study of Manek and Barudin (2017). This indicates when an increase in EG, it is expected to reduce the number of poor people. Based on the description, the hypothesis in this study is as follows.

\section{$\boldsymbol{H}_{3}$ : Economic Growth has a negative effect on District Poverty in Indonesia}

Community welfare is reflected in the living conditions of the community which can be seen from the standard of living of the community (Soesilowati, 2005). HDI is an indicator used to see the development of long-term development to measure success in 


\section{Handayani \& Badrudin \\ Evaluation of Village Fund Allocation on Indonesia}

building the quality of human life. In 2015, Indonesia's HDI reached 69.56. This shows that Indonesia's human development has increased but is still in a "moderate" status. Economic growth shows an increase in people's income from time to time. Therefore, economic growth will affect people's welfare. Sasana's study (2009) shows that EG has a significant effect and has a positive relationship to public welfare in the regency/city in Central Java Province. The same thing in the study of Soejoto et al. (2015) shows that EG provides significant positive effect on human development. Based on the description, the hypothesis in this research is as follows.

$\boldsymbol{H}_{4}$ : Economic Growth has a positive effect on District Social Welfare in Indonesia

\section{Research Method}

\section{Sample}

The sample selection method in this study was purposive sampling method (Sugiyono, 2011). The criteria used in sampling in this study are all districts in Indonesia that provide data on village funds allocation, capital expenditure, economic growth rate, percentage of poor population and human development index in 2015. This study used secondary data in 2015. By using purposive sampling method, there were 411 regencies having criteria in 2015.

\section{Data Analysis Model}

Data analysis model used in this research was Partial Least Square (PLS). Before performing PLS analysis, Klassen typology analysis was performed. Klassen typology analysis was based on the Gross Regional Domestic Product (GRDP) (Widodo, 2006). The technique of Klassen typology analysis is presented in four quadrants describing the position of each district in Indonesia. Based on the techniques of Klassen typology analysis, the districts in Indonesia are grouped into 4 quadrants.

1. Quadrant I: developing areas, the districts having average district GRDP growth rate greater than or equal the average growth rate of Indonesia's GRDP but the average contribution of district GRDP smaller than the average GRDP of Indonesia.

2. Quadrant II: prime areas, the districts having average district GRDP growth rate bigger or equal to the average growth rate of Indonesia's GRDP and mean contribution of district GRDP bigger or equal to the mean growth rate of GRDP of Indonesia.

3. Quadrant III: potential areas, the districts having average district GRDP growth rate less than the average growth rate of Indonesia's GRDP but the average rate of district GRDP contribution bigger or equal to the mean of GRDP of Indonesia. 
4. Quadrant IV: backward areas, the districts having an average growth rate of district GRDP less than average growth rate of Indonesia's GRDP and average of contribution of district GRDP smaller than the average GRDP of Indonesia.

Based on the position of each district, thus the development policy of the district government in Indonesia can be determined.

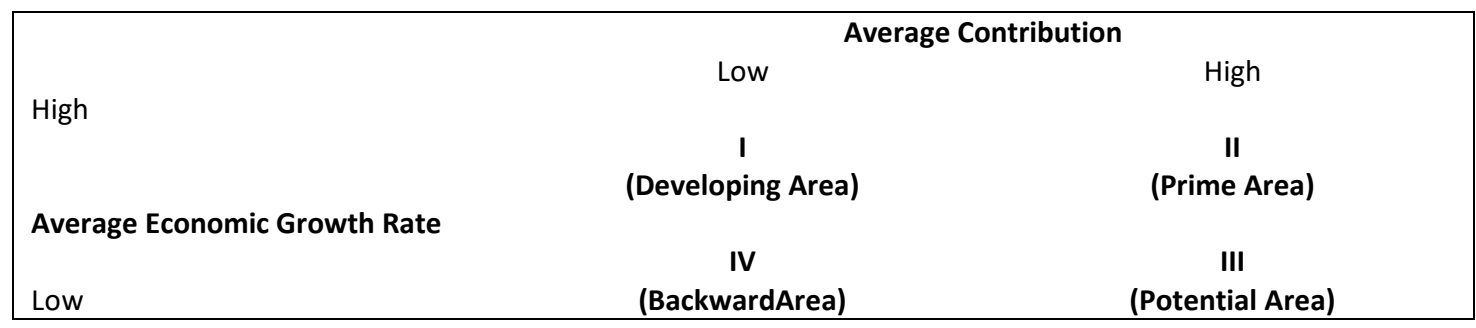

Figure 1 The Position of the Area Based on Klassen Typology Source: Widodo (Perencanaan Pembangunan: Aplikasi Komputer (Era Otonomi Daerah), 2006)

The line diagram construction can be seen in Figure 2 .

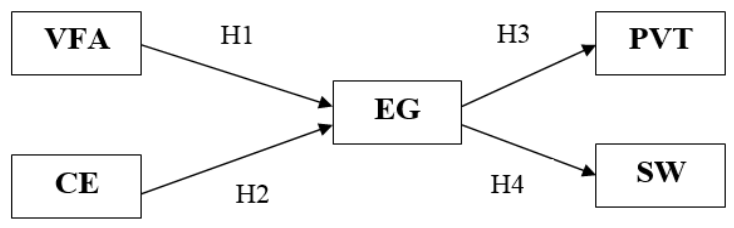

Figure 2 Line Diagram of Research Model

Information:

\begin{tabular}{ll} 
VFA & : Village Fund Allocation \\
CE & : Capital Expenditure \\
EG & $:$ Economic Growth \\
PVT & : Poverty \\
SW & $:$ Social Welfare \\
\hline & $:$ Influence between Variables \\
& $:$ Observation Variable
\end{tabular}

\section{Result and Discussion}

\section{Descriptive Statistics Analysis}

Village Fund Allocation (VFA) was measured from realization data of VFA in rupiah unit. Capital Expenditure (CE) was measured from realization data of CE in rupiah unit, Economic Growth (EG) was measured by growth of Gross Regional Domestic Product 
(GRDP) in \%, Poverty (PVT) was measured by the percentage of the poor, and Social Welfare was measured by Human Development Index (HDI).

Table 1 Descriptive Statistics of Districts in Indonesia

\begin{tabular}{lrrrrrr}
\hline Descriptive Statistics & \multicolumn{1}{c}{ VFA (Rp) } & \multicolumn{1}{c}{ CE (Rp) } & EG (\%) & PVT (\%) & \multicolumn{1}{c}{ SW } \\
\hline N & 411 & 411 & 411 & 411 & 411 \\
Mean & 49.626 .357 .000 & 323.597 .609 .939 & 0,057 & 14,76 & 65,39 \\
Minimum & 8.728 .910 .000 & 51.980 .727 .019 & $(0,115)$ & 2,33 & 39,41 \\
Maximum & 222.413 .168 .000 & 2.820 .501 .942 .494 & 1,07 & 45,74 & 81,20 \\
Standard Deviation & 30.652 .345 .000 & 238.636 .278 .129 & 0,065 & 8,34 & 5,50 \\
\hline
\end{tabular}

Descriptive statistics analysis aims to facilitate reading and understanding the data used in
research. The information is given in the form of research variable characteristics, including mean, maximum, minimum, and standard deviation of each variable.

\section{Klassen Typology Analysis}

The characteristics of districts in Indonesia are based on the mapping of Klassen Typology as shown in Figure 3.

\begin{tabular}{|ccc|}
\hline & \multicolumn{2}{c|}{ Average Contribution } \\
High & Low & High \\
(above average) & & Prime Area \\
& Developing Area & 30 districts \\
Average Economic Growth Rate & 118 districts & $7 \%$ \\
& $56 \%$ & Potential Area \\
low & & 99 districts \\
(below average) & Backward Area & $24 \%$ \\
\hline
\end{tabular}

Figure 3 Characteristics of Districts in Indonesia Based on Klassen Typology Source: Widodo (Perencanaan Pembangunan: Aplikasi Komputer (Era Otonomi Daerah), 2006)

\section{Partial Least Square Analysis (PLS)}

\section{a. Testing and Hypothesis Discussion of districts in Indonesia}

Based on the results of testing the VFA hypothesis on the EG of districts in Indonesia, it is showed that VFA has negative and significant effects on EG of the districts in Indonesia. Hypothesis testing results can be seen from the coefficient of -0.081 and $p$-value of 0.049. The results of this study do not support the research conducted by Prasetyo that state that VFA can increase the improvement of regional economy and GRDP.

Table 2. The Results of Hypothesis on Districts in Indonesia

\begin{tabular}{lccccc} 
Variable Relations & Path Coefficient & $p$-Values & Prediction & Result & Hypothesis \\
\hline VFA $\rightarrow$ EG & -0.081 & 0.049 & + & - & Rejected \\
CE $\rightarrow$ EG & -0.127 & $<0.001$ & + & - & Rejected \\
EG $\rightarrow$ PVT & 0.150 & 0.016 & - & + & Rejected \\
EG $\rightarrow$ PW & -0.152 & $<0.001$ & + & - & Rejected \\
\hline
\end{tabular}

Significant at the $p$-value $\leq 5 \%$. 


\section{Handayani \& Badrudin \\ Evaluation of Village Fund Allocation on Indonesia}

Based on the results of the second hypothesis testing, CE has negative and significant effect on the EG of the districts in Indonesia. The results of hypothesis testing can be seen from the coefficient value of -0.127 and $p$-value $<0.001$. The results of this study do not support the research conducted by Hakim and Wijayanti (2012) and Nurmainah (2013).

Based on the results of the third hypothesis testing, EG affects the PVT of districts in Indonesia. The results of hypothesis testing can be seen from the coefficient value of 0.150 and $p$-value 0.016 , which means that EG has a positive and significant impact on the PVT of districts in Indonesia. The results of this study do not support to the study of Ginting and Dewi (2013) which shows that EG has a negative and significant effect on PVT, but support to study of Manek and Badrudin (2017). That is, economic growth has not given effect in reducing the level of poverty that occurs in Indonesia.

Based on the result of the hypothesis test, EG the prosperity of the societies in Indonesia's district. The results of hypothesis testing can be seen from the coefficient value of -0.152 and $p$-value $<0.001$, which means that EG has negative and significant effects on the PVT of districts in Indonesia. The results of this study do not support research conducted by Sasana (2009) which shows that EG has positive and significant impacts on social welfare.

\section{b. Hypothesis Testing and Discussion Each Quadrant}

Based on the testing results of the first hypothesis in districts in quadrant I and II, it shows that the VFA does not affect the EG. It can be seen from the coefficient value of quadrant I and II, -0.081 and -0.203 . P-value on quadrant I and II are 0.184 and 0.037 . The results of this study support to Ashari's study (2013). While the districts in quadrant III and IV show that the VFA has positive effect which is significant on EG. This can be seen from the lines coefficient of quadrant III and IV of 0.415 and 0.211 , having $p$-value less than or equal to 5\%.The results of this study support to Prasetyo's study (2012) which states VFA able to increase the regional economic improvement and GRDP.

Table 3 The Results of Hypothesis each Quadrant

\begin{tabular}{|c|c|c|c|c|c|c|}
\hline Variable Relations & Quadrant & Path Coefficient & P-Value & Prediction & Result & Hypothesis \\
\hline \multirow[t]{4}{*}{$\mathrm{VFA} \rightarrow \mathrm{EG}$} & 1 & -0.081 & 0.184 & + & - & Rejected \\
\hline & II & -0.203 & 0.037 & + & - & Rejected \\
\hline & III & 0.415 & $<0.001$ & + & - & Supported \\
\hline & IV & 0.211 & 0.003 & + & - & Supported \\
\hline \multirow[t]{4}{*}{$\mathrm{CE} \rightarrow \mathrm{EG}$} & 1 & 0.071 & 0.218 & + & + & Rejected \\
\hline & II & -0.133 & 0.222 & + & - & Rejected \\
\hline & III & 0.316 & $<0.001$ & + & + & Supported \\
\hline & IV & -0.442 & $<0.001$ & + & - & Rejected \\
\hline \multirow[t]{4}{*}{$\mathrm{EG} \rightarrow \mathrm{PVT}$} & 1 & 0.458 & $<0.001$ & - & + & Rejected \\
\hline & II & 0.274 & 0.048 & - & + & Rejected \\
\hline & III & -0.092 & 0.177 & - & - & Rejected \\
\hline & IV & 0.140 & 0.033 & + & + & Rejected \\
\hline \multirow[t]{4}{*}{$E G \rightarrow S W$} & I & 0.420 & $<0.001$ & + & + & Supported \\
\hline & II & -0.175 & 0.153 & + & - & Rejected \\
\hline & III & 0.107 & 0.140 & + & + & Rejected \\
\hline & IV & -0.015 & 0.422 & + & - & Rejected \\
\hline
\end{tabular}

Significant at the $p$-value $\leq 5 \%$. 


\section{Handayani \& Badrudin \\ Evaluation of Village Fund Allocation on Indonesia}

Based on the testing results of the second hypothesis in districts located in quadrant I, it can be seen that CE has positive effect, but it is not significant to EG. It can be seen from the path coefficient and $p$-value, 0.071 and 0.218 respectively. The results of this test indicate that hypothesis 2 on quadrant I is not supported. The test results in Quadrant II and IV show that CE does not affect EG. This can be seen from the path coefficient values are just -0.133 and -0.442 , and the $p$-value is 0.222 and $<0.001$. In testing quadrants I, II, and IV support the research of Badrudin (2012). Different from the quadrant III, the test results show that CE has positive effect which is significant to EG. This can be seen from the path coefficient value and p-value of 0.316 and $<0.001$, meaning that hypothesis 2 on quadrant III is supported. The results support the study of Hakim and Wijayanti (2012) and Nurmainah (2013).

Based on the results of the third hypothesis testing in the districts located in quadrants I, II and III, it shows that EG has a positive effect which is significants on PVT. This can be seen from the path coefficient $(0.458,0.274,0.140)$ and $p$-value $(<0.001,0.048,0.033)$, which means that it is not supported. Test results in quadrant I, II and III show support the research by Badrudin (2012). Different from the quadrant IV, the testing result of EG has negative effect, but it is not significant to PVT. This can be seen from the path coefficient value and p-value of -0.092 and 0.177 , meaning that hypothesis 3 on quadrant III is supported. Test results in all regions do support the findings of Ginting and Dewi (2013) and Widianto, Erni, and Nurmansyah (2016).

Based on the results of the fourth test in the districts located in the quadrant $\mathrm{I}$, it shows that EG has a positive effect which is significant on SW, it can be seen from the results of coefficient and $p$-value of 0.420 and $<0.001$ which means that the hypothesis 4 on quadrant I is supported. The results of this test support to study of Sasana (2009) and Adelfina and Jember (2016). While in quadrant II, III and IV, it is not supported; this can be seen from the coefficient value and $p$-value $(-0,175 ; 0,107 ;-0,015)$ and $(0,153 ; 0,140$; $0,422)$. The results of this test do not support the research Sasana (2009), Soejoto et al. (2015) and Badrudin (2012).

\section{Conclusion}

Based on the test results in this study, it can be concluded that VFA has a significant positive effect on EG in potential and backward areas. This shows that potential and backward areas are starting to use VFA effectively to support village development. VFA is proven to have no effect on EG in developing and prime areas. This study shows CE has a significant positive effect on EG only in potential areas. This shows that when there is an increase in CE for development financing, it will be followed by an everincreasing EG. CE proved to have no effect on backward, developing and prime areas. This shows that there is no CE ranking for development funding. The study also found that EG did not have an effect on poverty in all districts. It can be concluded that overall the ongoing development in Indonesia is an exclusive development. EG only has a significant positive effect on SW in the developing area. This shows that developing area 


\section{Handayani \& Badrudin \\ Evaluation of Village Fund Allocation on Indonesia}

has succeeded in carrying out inclusive development. Thus, in addition to developing area, development is still exclusive.

The implication of the results of this study is the need for VFA evaluation so that the allocation of village funds can run effectively. The evaluation of the VFA can be in the form of maximum socialization of government regulations, adequate human resource capacity, and channelling of funds, as well as appropriate use of funds. So that it can reduce the use of funds outside the priorities and potential misappropriation of VFA. Effective implementation of VFA will support village development so that welfare will increase.

In this study, a limitation exists namely only analyze the VFA data for one year period. Likewise for CE, EG, PVT and SW, there is only data available in the period of 2015. With the limited data available, the results of this study have not shown maximum results. Based on this limitations, it is recommended that further researchers will consider i) to add the number of years for VFA research, in order to obtain maximum results, ii) adding other indicators for SW variables such as the Gini Index each district, so as to illustrate the VFA has been allocated effectively and can reduce inequality, and iii) government regulations that support VFA must be clear so that there is no ambivalence.

\section{Acknowledgement}

We would like to thank for KEMENRISTEKDIKTI Republic of Indonesia for the funding of this Research through Penelitian Strategi Nasional scheme in 2018.

\section{References}

Ashari, N. (2013). Implementasi Alokasi Dana Desa di Desa Kelinjau Kecamatan Muara Ancong Kabupaten Kutai Timur. Jurnal Ilmu Pemerintaban, 1, 1135-1144. Retreived from: https://ejournal.ip.fisip-unmul.ac.id/site/?p=778\#

Aziz, N. L. (2016). Otonomi Desa dan Efektivitas Dana Desa. Penelitian Politik, 13(2), 193 211. https://doi.org/10.14203/ipp.v13i2.575

Badan Pusat Statistik. (2015). Berita Resmi Statistik, "Profil Kemiskinan Indonesia Maret 2015", No 86/09/Th. XVIII,. Jakarta: Badan Pusat Statistik.

Badan Pusat Statistik. (2016). Berita resmi statistik Indeks Pembangunan Manusia, No. 57/06/Th. XIX. Jakarta: Badan Pusat Statistik.

Badrudin, R. (2011). Effect of Fiscal Decentralization on Capital Expenditure, Growth, and Welfare. Emerging Market, 3, 211-223. Retreived from: https://journal.uii.ac.id/JEP/article/view/2974

Badrudin, R. (2012). Pengarub Desentralisasi Fiskal terbadap Belanja Modal, Pertumbuban Ekonomi, dan Kesejabteraan Masyarakat Kabupaten/kota di Provinsi Jawa Tengah. Surabaya: Universitas Brawijaya.

Badrudin, R. (2017). Ekonomika Otonomi Daerah (2 ed.). Yogyakarta: UPP STIM YKPN.

Badrudin, R., \& Kuncorojati, I. (2017). The Effect of District Own-Source Reveneu and Balance Fund on Public Welfare by Capital Expenditure and Economic Growth as 
an Intervening Variable in Special District of Yogyakarta. Manajemen dan Kewirausahaan, 19(1), 54-59. https://doi.org/10.9744/imk.19.1.54-59

Badrudin, R., \& Siregar, B. (2015). The Evaluation of The Implementation of Regional Autonomy in Indonesia. Emerging Market, 7(1), 117-130.

https://doi.org/10.20885/ejem.vol7.iss1.art1

Donaldson, \& Davis, J. (1991). Stewardship Theory or Agency Theory: CEO Governance and Shareholder Returns, Australian Journal of Management, 16(1), 49-64. https://doi.org/10.1177/031289629101600103

Ginting, A., \& Dewi, G. (2013). Pengaruh Pertumbuhan Ekonomi dan Pertumbuhan Sektor Keuangan terhadap Pengurangan Kemiskinan di Indonesia. Ekonomi dan Kebijakan Publik, 4, 117-130.

Hakim, L., \& Wijayanti, A. (2014). Pengaruh Belanja Modal terhadap Pertumbuhan Ekonomi, Jurnal Ilmiah Mahasiswa Fakultas Ekonomi dan Bisnis, 3(1). Retreived from: https://iimfeb.ub.ac.id/index.php/jimfeb/article/view/1499

Harian Kompas. (25 April 2017). "Pembangunan Manusia: Masalah Disparitas". Harian Kompas. Lai, C. (1994). Market structure and Inter-industry Profit Differences in Taiwan. Pakistan Development Review, 33(2), 147-163. https://doi.org/10.30541/v33i2pp.147-163

Lin, J. Y., \& Liu, Z. (2000). Fiscal Decentralization and Economic Growth in China, in Economic. Economic Development and Cultural Change, 49(1), 1-21. https://doi.org/10.1086/452488

Manek, M. \& Badrudin, R. (2016). Pengaruh Pendapatan Asli Daerah Dan Dana Perimbangan Terhadap Pertumbuhan Ekonomi Dan Kemiskinan Di Provinsi Nusa Tenggara Timur. Telaah Bisnis, 17(2), 81-98. http://dx.doi.org/10.35917/tb.v17i2.49

Nugroho, F. (2012). Pengaruh Belanja Modal terhadap Pertumbuhan Kinerja Kenangan Daerah dengan Pendapatan Asli Daerah sebagai Variabel Intervening (Studi Kasus di Propinsi Jateng). Semarang: Universitas Diponegoro.

Nurmainah, S. (2013). Analisis Pengaruh Belanja Modal Pemerintah Daerah, Tenaga Kerja Terserap Dan Indeks Pembangunan Manusia Terhadap Pertumbuhan Ekonomi Dan Kemiskinan (Studi Kasus 35 Kabupaten/Kota Di Provinsi Jawa Tengah). Jurnal Bisnis dan Ekonomi, 20(2), 131-141. Retrieved from: https://www.unisbank.ac.id/ojs/index.php/fe3/article/view/3158

Peraturan Pemerintah No 72 Tabun 2005 tentang Desa. Jakarta: Departemen Dalam Negeri.

Prasetyo, E. P. (2012). Dampak Alokasi Dana Desa pada Era Desentralisi Fiskal terhadap Perekonomian Daerah di Indonesia. Disertasi. Bogor: Institut Pertanian Bogor.

Raharjo, E. (2007). Teori Agensi dan Teori Stewarship dalam Perspektif Akuntansi. Fokus Ekonomi : Jumal Ilmiah Ekonomi, 2(1), 37-46. https://doi.org/10.34152/fe.2.1.\%25p

Sasana, H. (2009). Analisis Dampak Pertumbuhan Ekonomi, Kesenjangan antar Daerah dan Tenaga Kerja Terserap terhadap Kesejahteraan di Kabupaten/Kota Provinsi Jawa Tengah dalam Era Desentralisasi Fiskal. Ekonomi Pembangunan, 16, 50 -69. https://doi.org/10.23917/jep.v7i2.3985

Siregar, B., \& Badrudin, R. (2017). Degree of Fiscal Decentralization and Flypaper Effect: Evidence from Indonesia.Advanced Science Letters. Advanced Science Letters, 23(9), 9013-9019. https://doi.org/10.1166/as1.2017.10014

Soejoto, A., Subroto, T., \& Suyanto. (2015). Fiscal Decentralization Policy in Promoting Indonesia Human Development. International Journal of Economics and Financial Issues, 5(3), 763-771. Retrieved from: https://www.econjournals.com/index.php/ijefi/article/view/1314

Soesilowati, E. S. (2005). Pengarub Desentralisasi Fiskal terhadap Kesjabteraan Masyarakat: Kinerja Pelayanan Publik di Bidang Pendidikan dan Kesehatan, Jakarta: Pusat Penelitian Ekonomi Lembaga Ilmu Pengeta. 
Handayani \& Badrudin

Evaluation of Village Fund Allocation on Indonesia

Sugiyono. (2011). Metode Penelitian Kuantitatif Kualitatif dan Re D. Bandung: Alfabeta. Tuasikal, A. (2008). Pengaruh DAU, DAK, PAD dan PDRB Terhadap Belanja Modal Pemerintah Daerah Kabupaten/Kota di Indonesia. . Jurnal Telaab \& Riset Akuntansi, 1(2), 142-155. Retrieved from: http://jurnal.unsyiah.ac.id/TRA/article/view/299

Undang-undang no 6 Tabun 2014 tentang Desa . Jakarta: Departemen Dalam Negeri.

United Nations Development Program (UNDP). (2009). Retrieved from: bttp:/ / www.undp.org/content/ undp/en/ home/librarypage/corporate/ undp in action 2009. htm $\underline{l}$

Widianto, A., Erni, U., \& Nurmansyah, A. (2016). Pengaruh Alokasi Dana Umum, Dana Alokasi Khusus dan Belanja Modal terhadap Pertumbuhan Ekonomi dan Tingkat Kemiskinan (Studi Kasus pada Kota Tegal). Journal Research Accounting Politeknik Tegal, 5(2). http://dx.doi.org/10.30591/monex.v5i2.417

Widodo, T. (2006). Perencanaan Pembangunan: Aplikasi Komputer (Era Otonomi Daerah). Yogyakarta: UPP STIM YKPN. 